\title{
Puyehue-Cordón Caulle eruption of 2011: tephra fall and initial forest responses in the Chilean Andes
}

\author{
Erupción del complejo Puyehue-Cordón Caulle en 2011: \\ caída de tefra y respuestas forestales iniciales en Los Andes chilenos
}

\author{
Frederick J Swanson ${ }^{\text {a* }}$, Julia Jones ${ }^{\text {b }}$, Charlie Crisafulli c, Mauro E González ${ }^{\text {d,e }}$, Antonio Lara ${ }^{\text {d,e }}$ \\ *Corresponding autor: a Pacific Northwest Research Station, US Forest Service, 3200 Jefferson Way, \\ Corvallis, Oregon 97331, USA, phone: 541 757-8441, fred.swanson@oregonstate.edu \\ ${ }^{\mathrm{b}}$ Oregon State University, College of Earth, Ocean, and Atmospheric Sciences, Corvallis, Oregon, USA. \\ ${ }^{\mathrm{c}}$ Pacific Northwest Research Station, US Forest Service, Olympia, Washington, USA. \\ ${ }^{d}$ Universidad Austral de Chile, Facultad de Ciencias Forestales y Recursos Naturales,Instituto de Conservación, \\ Biodiversidad y Territorio, Valdivia, Chile. \\ ${ }^{\mathrm{e}}$ Center for Climate and Resilience Research $(\mathrm{CR})^{2}$, Chile.
}

\begin{abstract}
SUMMARY
The 2011 eruption in the Puyehue-Cordón Caulle volcanic complex deposited up to $50 \mathrm{~cm}$ of tephra in a plume that intersected the crest of the Andes along Route 215, offering an excellent opportunity to study disturbance effects on native forests along a gradient of tephra depth. Our observations focused on short-term, species-level, tree mortality and sprouting and tephra fall effects on foliage and limb fall. More than $80 \%$ of the thickest deposits were composed of a basal, pumice, gravel layer containing individual clasts up to $6 \mathrm{~cm}$ in length overlain by finer gravel and capped by several $\mathrm{cm}$ of sandy tephra. In a sample of four plots with tephra thickness ranging from 10 to $50 \mathrm{~cm}$, we observed a wide range of tree mortality: about $8 \%$ of stems living at the time of the eruption were killed by $10 \mathrm{~cm}$ of tephra fall and $54 \%$ were killed by $50 \mathrm{~cm}$. However, properties of the affected forest, such as species composition, foliage sprouting and retention (deciduous versus evergreen) characteristics, and tree size/age, strongly influenced survival. The sites with 35 and $50 \mathrm{~cm}$ thick deposits were dominated by the deciduous tree Nothofagus pumilio, which was leafless in the austral winter, season of the initial phase of the eruption. The evergreen tree $N$. dombeyi experienced much higher mortality. The low density of the falling pumice particles appeared to cause minimal abrasion of the canopy.
\end{abstract}

Key words: forest disturbance, Puyehue-Cordón Caulle, tephra fall, volcanic disturbance.

\section{RESUMEN}

La erupción en el año 2011 del complejo volcánico Puyehue-Cordón Caulle depositó hasta 50 cm de tefra en la pluma que interceptó las altas cumbres de Los Andes sobre la ruta 215, ofreciendo una excelente oportunidad para el estudio de los efectos del disturbio sobre los bosques nativos a lo largo de un gradiente de profundidad de tefra. Las observaciones se enfocaron en el corto plazo, a nivel de especies, respecto de la mortalidad arbórea y aparición de rebrotes. Más del $80 \%$ de los depósitos más gruesos estuvieron compuestos de un estrato basal de pumicita y recubierta por varios centímetros de tefra arenosa. En un muestreo de cuatro parcelas con un espesor de tefra que varió de 10 a $50 \mathrm{~cm}$, se observó un amplio rango de mortalidad arbórea: alrededor del $8 \%$ y $54 \%$ de los árboles vivos al momento de la erupción murieron, con $10 \mathrm{~cm}$ y $50 \mathrm{~cm}$ de profundidad de tefra, respectivamente. Sin embargo, ciertos atributos de los bosques afectados, tales como la composición de especies, capacidad de rebrote del follaje, capacidad de retención de tefra (perennes vs deciduos) y tamaño/edad de los árboles, influenciaron fuertemente la sobrevivencia. Los sitios con un espesor de depósitos de 35 y $50 \mathrm{~cm}$ fueron dominados por la especie decidua Nothofagus pumilio, la cual se encontraba sin follaje en el invierno del hemisferio austral durante la fase inicial de la erupción. La mayor parte de estos árboles sobrevivieron y produjeron follaje vigoroso al año siguiente (2012). La especie arbórea siempreverde $N$. dombeyi presentó una mayor mortalidad. En síntesis, la respuesta arbórea inicial estuvo determinada tanto por las características de las especies como por el espesor de la tefra.

Palabras clave: caída de tefra, disturbio forestal, disturbio volcánico, Puyehue-Cordón Caulle.

\section{INTRODUCTION}

Active volcanoes surrounded by native forest are a dominant feature of the landscape of the Andes in the tem- perate latitudes of Chile and adjacent Argentina (Donoso et al. 2014). Volcanic eruptions are important disturbance processes in forests globally, and the enormous diversity of volcanic processes has a wide range of physical and 
chemical effects on ecosystems (Ayris and Delmelle 2012, Donoso et al. 2014, Crisafulli et al. 2015). This paper addresses the effects of tephra fall, the aerial deposition of particulate volcanic ejecta, on native forests; these effects have received limited attention in forest ecology literature, despite the broad extent of tephra fall and forest cover.

The 2011 eruption of the Puyehue-Cordón Caulle volcanic complex in south-central Chile provides an excellent opportunity to assess some aspects of volcano-ecology interactions. Tephra fall is the most extensive product of explosive volcanism, as exhibited in the Caulle eruption, and it has a wide range of effects on natural resources and human society, as well as ecosystems (Ayris and Delmelle 2012). This eruption deposited pumice-rich tephra southeast of the vent, blanketing native forest with up to $50 \mathrm{~cm}$ in the area along Route 215 between the Chilean and Argentinean border crossing stations in areas located within Puyehue and Nahuel Huapi National Parks.

The objective of our study is to understand effects of tephra fall on native forests. Initially we hypothesize that larger tephra deposit thickness results in larger impact on forests, including tree mortality, but we also anticipate that properties of tephra, such as bulk density, and species also affect the response. While this study is limited to the 2011 eruption of Caulle, we examine general concepts about ecological effects of volcanic eruptions by comparing observations at Caulle, Chaitén (Pallister et al. 2010, Swanson et al. 2013), and Mount St. Helens in the northwestern US, since its 1980 eruption (Dale et al. 2005). Key points of comparison include tephra properties (e.g., low-density pumice vs. dense lithic particles), properties of vegetation (e.g., evergreen vs. deciduous, presence/absence of ability to sprout), and eruption timing (e.g., in relation to stage of phenology and succession of vegetation).

\section{METHODS}

Study area. We visited the Route 215 area (figure 1) in January 2012 and installed plots to assess initial effects of volcanic processes on forest trees in terms of tree mortality, damage-induced sprouting, and foliage and limb removal. We revisited the plots briefly in January 2013 and December 2013 to make qualitative assessments of change. This work is done in conjunction with our similar studies of the 2008-2009 eruption of Chaitén volcano, located 265 $\mathrm{km}$ to the south (Pallister et al. 2010, Swanson et al. 2013).

The Caulle eruption began on June 4, 2011, from a vent in the rift system extending northwest from Puyehue strato volcano in the Chilean Andes (40.59S, 72.12 W) ${ }^{1}$ (Singer et al. 2008). This volcanic complex erupted frequently in recorded history, most recently in 1960 . The 2011 eruption produced a rhyolite lava flow and pyroclastic flows close to the vent. It sent tephra to the SE to ESE, blanketing parts of the Chilean Andes, central Argentina, and the southern At-

http://www.volcano.si.edu/volcano.cfm?vn=357150 lantic Ocean (Castro et al. 2013). The axis of the tephra plume intersected Route $21520 \mathrm{~km}$ southeast of the vent where tephra deposits were approximately $50 \mathrm{~cm}$ thick. Route 215 served as a convenient transect over the Andes that permitted sampling along a gradient of tephra fall effects on the native Valdivian temperate rainforest from approximately 900 to $1,300 \mathrm{~m}$ elevation. Forests in the study area, which we observed only after the eruption, appeared similar to those along the elevation gradient of forest types described from nearby Antillanca (Veblen et al. 1977). The lowest elevation site $(900 \mathrm{~m})$ was dominated by large individuals of Nothofagus dombeyi (Mirb.) Blume. and Laureliopsis philippiana (Looser) Schodde, with an understory dominated by Chusquea cuoleu Desv. Above $900 \mathrm{~m}$, forests were a mix between N. dombeyi and N. pumilio (Poepp. et Endl.) Kraser, with an understory including Drimys andina (Reiche) R.A. Rodr. et Quez. and several other shrub and herb species, but little evidence of Chusquea spp. Above 1,100 m, the forest graded to almost exclusively $N$. pumilio, with an understory of $D$. andina and other shrubs. Mean annual precipitation at Antillanca, $\sim 16 \mathrm{~km}$ to southwest of the study area, exceeded 5,600 mm (Veblen 1977).

Field sampling. We first visited the area in early January 2012 during the first growing season after the main phase of the eruption, although audible explosions and periodic tephra fall continued during our visit. We described tephra stratigraphy at 14 locations between the two border crossing stations and characterized vegetation at four sites on the Chilean side of the border: in one $100 \times 12 \mathrm{~m}$ plot at each of three sites, and a fourth plot was only $80 \times 12 \mathrm{~m}$, because of topographic constraints. Tephra deposit thickness was approximately $10,25,35$, and $50 \mathrm{~cm}$ at these sample sites. We identified these sample locations as sites TdN10 (mean thickness \pm 1 standard deviation $=10.5 \pm 2.1 \mathrm{~cm}$, number of sample pits $=2)$, $\operatorname{TdN} 25(25.4 \pm 2.6 \mathrm{~cm}, \mathrm{n}=5)$, $\operatorname{TdN} 35(37 \pm 0 \mathrm{~cm}, \mathrm{n}=3)$, and $\operatorname{TdN} 50(47.3 \pm 2.1 \mathrm{~cm}, \mathrm{n}=$ $3)$. Ideally, we wished to investigate effects of varying tephra thickness on forests with similar conditions (i.e., species, size/age, stem density), however forest community composition and structure varied as a function of elevation and stage of succession in response to earlier disturbance events, complicating the relationship between tephra thickness and tree response.

Within each plot we tallied all trees larger than $5 \mathrm{~cm}$ diameter at breast height (dbh), recorded species, measured dbh, and indicated whether the tree appeared to be (1) living, (2) dead before the eruption (based in part on stage of decomposition), or (3) probably killed in response to the eruption (absence of live foliage and no significant decomposition of fine branches evident). We noted extent and location of sprouting in the crown of each tree by visually estimating the area occupied by live sprouts as the percent cover of total available area for sprouting, distinguishing tree bole, branch, and twig locations (Swanson et al. 2013). We also took photographs and counted num- 

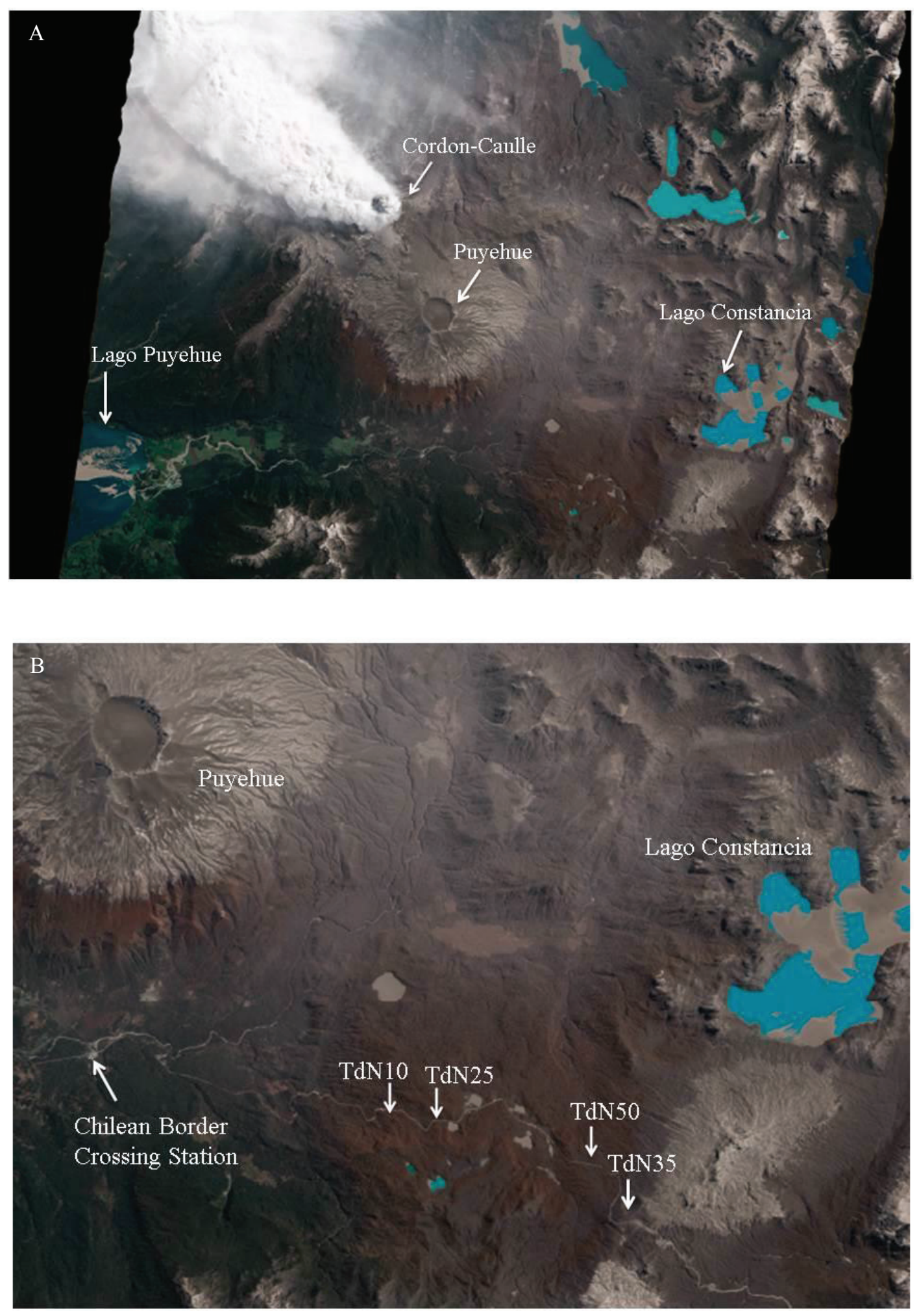

Figure 1. Remote sensing images of Caulle vent system and Puyehue strato volcano during the eruption in 2012. A) The Caulle vent emitting a plume being blown to the northwest. B) Location of sample plots along Route 215 over the Andes south of Puyehue. Rafts of floating pumice are visible on the lakes. Image from Oct. 22, 2012: http://earthobservatory.nasa.gov/NaturalHazards/event. php?id=50859.

Imagen satelital del sistema de conductos (chimeneas) del Cordón-Caulle y del estrato volcán Puyehue durante la erupción en el 2012. A) El conducto (chimenea) del Caulle emitiendo una pluma arrastrada por el viento hacia el noroeste. B) Ubicación de las parcelas de muestreo a lo largo de la ruta 215 en la cordillera andina al sur de Puyehue. Nótese la pumicita flotante visible sobre los lagos. Imagen del 22 de octubre, 2012. 
ber of fallen branches on the tephra deposit surface and measured their maximum diameter along a line extending down the center of the plot.

\section{RESULTS}

Tephra deposit stratigraphy and distribution. The profile of tephra deposit thickness along the Route 215 transect generally followed the elevation profile with maximum deposit thickness approximately one kilometer west of the crest of the Andes (figure 2). The tephra stratigraphy consisted of a surface layer of 1 to $2 \mathrm{~cm}$ of fine sand over 4 to $6 \mathrm{~cm}$ of fine gravel, which rested on 4 to $40 \mathrm{~cm}$ of gravel pumice. This coarse-textured, basal layer accounted for the variation in total deposit thickness along the Route 215 transect; depth of the fine sand and fine gravel layers did not vary consistently along this transect. Individual clasts within the basal unit were up to $6 \mathrm{~cm}$ in long axis at all four sample plots. These profile descriptions were made seven months after the main period of deposition, consequently some compaction and surface runoff had likely occurred.

Pre-eruption vegetation conditions and initial disturbance impacts. Environmental factors, such as temperature and precipitation influenced by elevation, and disturbance history before the 2011 eruption produced varied composition and size structure of pre-eruption forest vegetation in the sample sites (figure 3, table 1). Consequently, effects of the 2011 tephra fall reflected effects of differences in site environmental factors and pre-eruption forest characteristics, as well as variation in tephra deposit thickness. In this analysis we assumed that by visiting the site very soon after the main phase of the eruption we could interpret the forest composition and structure immediately before the eruption, although absence of foliage on some trees pre- vented confident identification of species, hence we reported them as unknown. We report our interpretation of live vs. killed tree status as of January 2012, but in follow up visit, such as December 2013, two and a half years after the eruption began, we observed limited sprouting of small understory trees and some large $N$. dombeyi at TdN35 and TdN50 that we interpreted as killed in the first sampling.

Site TdN10 (10 cm deposit thickness) was located at $912 \mathrm{~m}$ elevation, which is over $150 \mathrm{~m}$ lower than the other sample sites. The forest was dominated by Myrceugenia planipes (Hook. et Arn.) O. Berg and Laureliopsis philippiana, which were common at this elevation, though absent from the other higher elevation sampling sites. Nothofagus dombeyi was a significant component of the stand (10 out of the 84 trees sampled and a dominant contributor to basal area), however $N$. pumilio trees, which were present at the other three sites, were absent. Most of the trees were living (86 \%) at the time of January 2012 sampling. Sprouting of foliage was dominantly from twigs at the tips of the branch system (table 1). Branch-sized litter on the forest floor was uncommon (table 2). In general, the stand appeared not to have been strongly affected by the $10 \mathrm{~cm}$ of tephra deposition.

The TdN25 site was notable for high mortality: $88 \%$ of trees interpreted as living at the time of the eruption were scored as killed by the eruption when observed January 2012. This site was dominated by $N$. dombeyi in terms of both stem density and basal area at the time of the eruption, and all the individuals identified as killed by tephra deposition were $N$. dombeyi (table 1). Only five $N$. pumilio trees occurred in the plot, but these were large-diameter trees (mean dbh $58 \mathrm{~cm}$ ), and all were living and exhibited some sprouting from branches and tree boles. Branch litterfall density was the highest of the four sample sites, although still had rather low values (table 2).

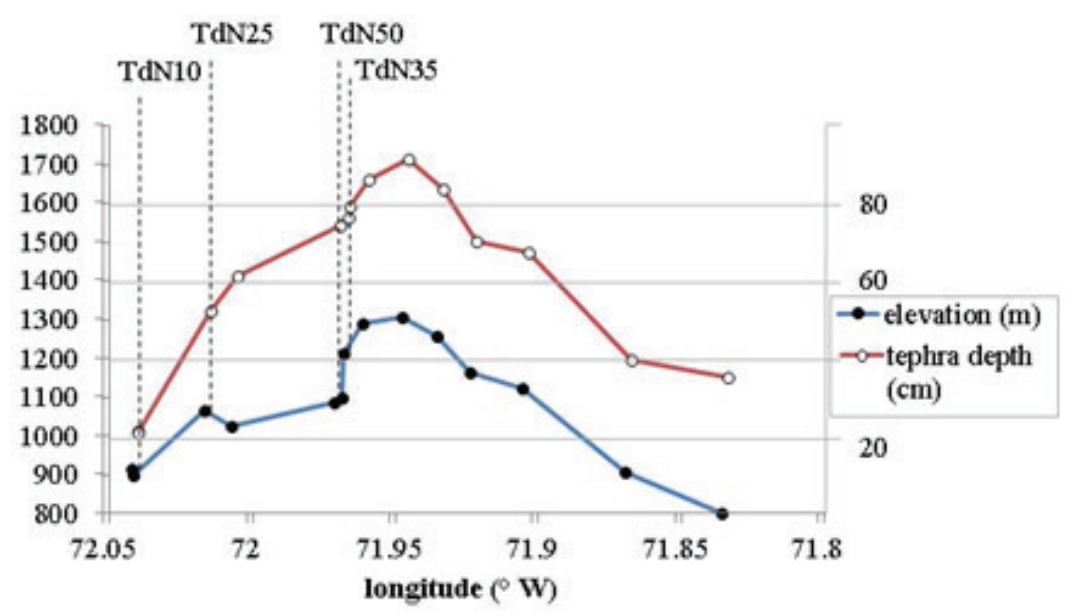

Figure 2. East-west transect of topography and tephra thickness plotted by longitude. Tephra thickness is shown for 10 sites in addition to the four plot sites.

Transecto Este-Oeste de topografía y espesor de tefra dibujado de acuerdo a la longitud. El espesor de la tefra es mostrado para 10 sitios adicionales a los cuatro sitios estudiados. 

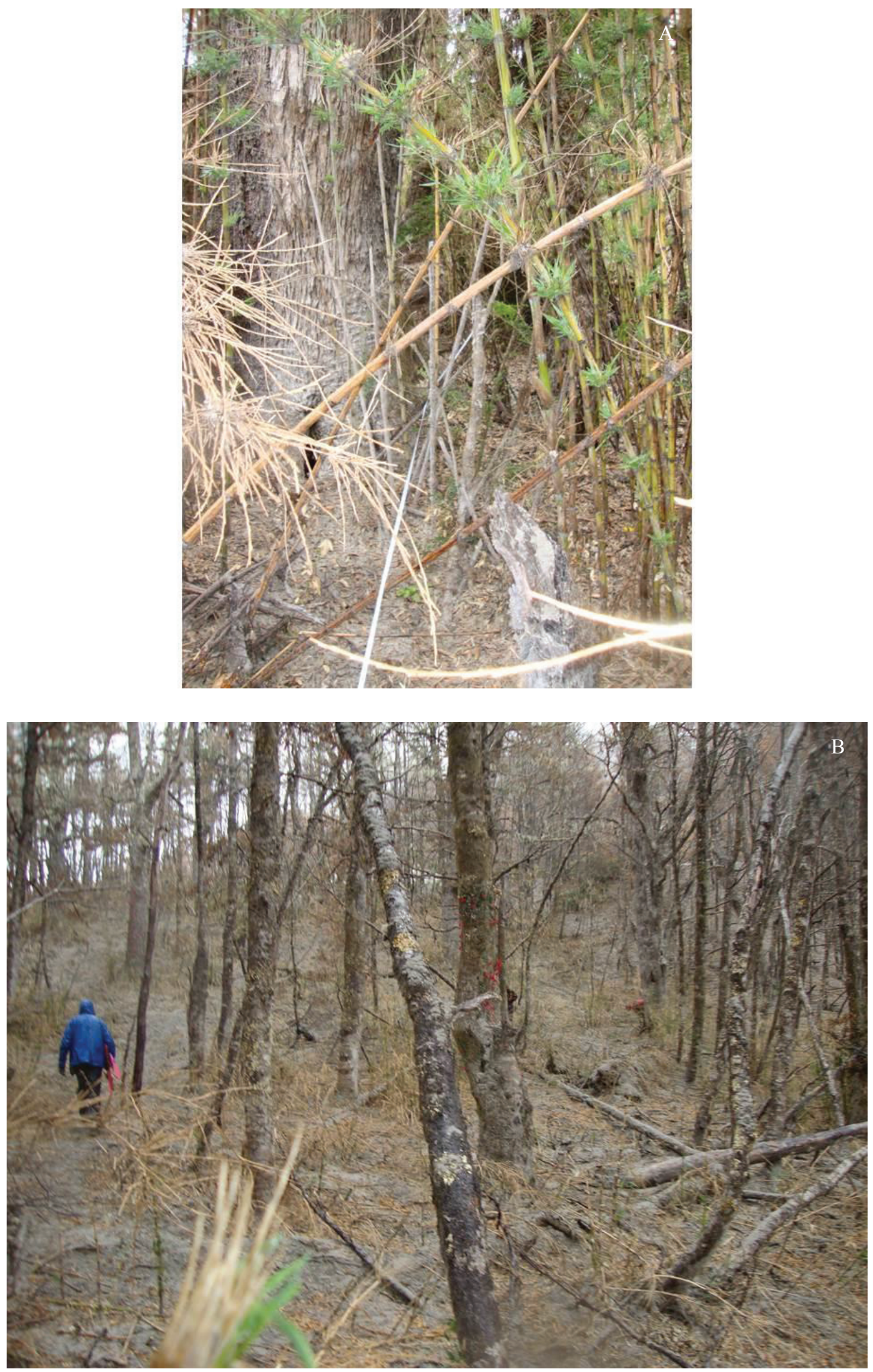

(Figure 3. Next page) 

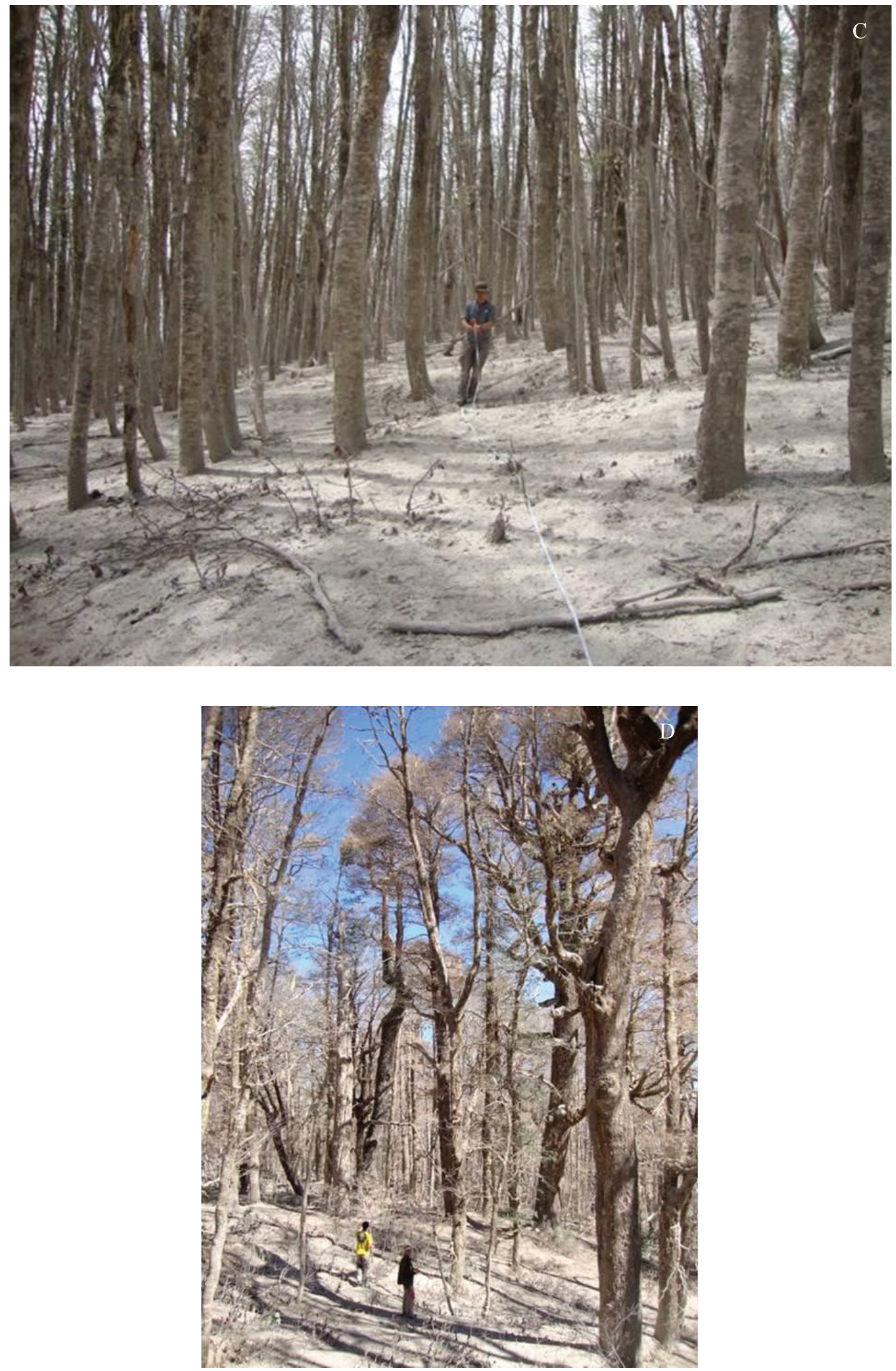

Figure 3. Photographs of forest conditions at sites: A) TdN10, B) TdN25, C) TdN35, and D) TdN50. All photos taken in Jan. 2012 by $\mathrm{J}$ Jones and F Swanson.

Fotografías de las condiciones del bosque en los sitios: A) TdN10, B) TdN25, C) TdN35 y D) TdN50. Todas las fotografías tomadas en enero 2012 por J. Jones y F. Swanson. 
Table 1. Characteristics of trees in sample sites affected by tephra fall from Caulle sampled in January 2012. All transects are $100 \mathrm{~m} x$ $12 \mathrm{~m}$, except TdN10 which was limited by topography to $80 \mathrm{~m}$ length. Percent of trees alive at the time of sampling, dead before the eruption and presumably killed as a result of tephra deposition, based on observations during the visit. Absence of foliage on some trees prevented confident identification of species, thus we report them as "unknown." Locations of sprouts on trees are noted as twigs, major branches, or trunk. "Total" row includes rare species. sd = standard deviation.

Características de los árboles en los sitios afectados por caída de tefra del Caulle muestreados en enero 2012 . Todos los transectos son de 100 m x $12 \mathrm{~m}$, excepto TdN10 el cual fue limitado por la topografía a un largo de $80 \mathrm{~m}$. Porcentaje de árboles vivos al momento del muestreo, muertos antes de la erupción, y árboles presumiblemente muertos como resultado del depósito de tefra, basado en observaciones durante la visita. La ausencia de follaje en algunos árboles no permitió una interpretación confiable de la especie, así esto se reporta como "desconocido". La ubicación de los rebrotes de los árboles son registrados como ramillas, ramas mayores, o tronco. "Total” incluye especies raras. sd = desviación estándar.

\begin{tabular}{|c|c|c|c|c|c|c|c|c|c|c|}
\hline \multirow[b]{2}{*}{ Species } & \multirow{2}{*}{$\begin{array}{l}\text { Stems } \\
\text { (no.) }\end{array}$} & \multirow[b]{2}{*}{ Stems/ha } & \multirow{2}{*}{$\begin{array}{c}\text { Mean } \\
\text { diameter } \\
(\mathrm{cm} \pm \mathrm{sd})\end{array}$} & \multirow{2}{*}{$\begin{array}{c}\text { Basal } \\
\text { area } \\
\left(\mathrm{m}^{2} \mathrm{ha}^{-1}\right)\end{array}$} & \multirow{2}{*}{$\begin{array}{l}\text { Live } \\
\%\end{array}$} & \multirow{2}{*}{$\begin{array}{c}\text { Dead } \\
\%\end{array}$} & \multirow{2}{*}{$\begin{array}{c}\text { Killed } \\
\%\end{array}$} & \multicolumn{3}{|c|}{ Sprouting from } \\
\hline & & & & & & & & $\begin{array}{c}\text { Twigs } \\
\% \\
\end{array}$ & $\begin{array}{c}\text { Branches } \\
\%\end{array}$ & $\begin{array}{c}\text { Trunks } \\
\%\end{array}$ \\
\hline \multicolumn{11}{|l|}{ Site: $\mathrm{TdN} 10$} \\
\hline Nothofagus dombeyi & 10 & 83 & $91 \pm 68$ & 102 & 80 & 0 & 20 & 70 & 40 & 0 \\
\hline Laureliopsis philippiana & 20 & 167 & $22 \pm 16$ & 12 & 100 & 0 & 0 & 75 & 55 & 20 \\
\hline Myrceugenia planipes & 42 & 350 & $16 \pm 7$ & 10 & 88 & 0 & 12 & 88 & 69 & 0 \\
\hline Podocarpus nubigena & 1 & 8 & $23 \pm 0$ & 0 & 100 & 0 & 0 & 100 & 100 & 0 \\
\hline Unknown & 5 & 42 & $64 \pm 51$ & 25 & 0 & 100 & 0 & 0 & 0 & 0 \\
\hline Total & 84 & 875 & $30 \pm 37$ & 155 & 86 & 6 & 8 & 76 & 57 & 6 \\
\hline \multicolumn{11}{|l|}{ Site: TdN25 } \\
\hline Nothofagus dombeyi & 87 & 725 & $19 \pm 21$ & 45 & 6 & 9 & 85 & 6 & 1 & 0 \\
\hline Nothofagus pumilio & 5 & 33 & $58 \pm 34$ & 11 & 100 & 0 & 0 & 75 & 50 & 25 \\
\hline Unknown & 12 & 100 & $24 \pm 31$ & 12 & 0 & 100 & 0 & 0 & 0 & 0 \\
\hline Total & 104 & 867 & $21 \pm 24$ & 67 & 10 & 18 & 72 & 8 & 3 & 1 \\
\hline \multicolumn{11}{|l|}{ Site: TdN35 } \\
\hline Nothofagus dombeyi & 0 & 0 & -- & 0 & -- & -- & -- & -- & -- & -- \\
\hline Nothofagus pumilio & 267 & 2225 & $16 \pm 8$ & 53 & 75 & 22 & 2 & 75 & 75 & 2 \\
\hline Unknown & 1 & 8 & $9 \pm 0$ & 0 & 0 & 100 & 0 & 0 & 0 & 0 \\
\hline Total & 268 & 2233 & $16 \pm 8$ & 53 & 75 & 23 & 2 & 75 & 74 & 2 \\
\hline \multicolumn{11}{|l|}{ Site: TdN50 } \\
\hline Nothofagus dombeyi & 35 & 292 & $27 \pm 32$ & 40 & 3 & 3 & 89 & 3 & 3 & 0 \\
\hline Nothofagus pumilio & 42 & 350 & $25 \pm 23$ & 31 & 83 & 0 & 17 & 76 & 14 & 0 \\
\hline Unknown & 8 & 50 & $14 \pm 7$ & 1 & 0 & 50 & 33 & 0 & 0 & 0 \\
\hline Total & 85 & 708 & $25 \pm 26$ & 74 & 43 & 8 & 50 & 39 & 8 & 0 \\
\hline
\end{tabular}

Table 2. Number of branches on the ground per $100 \mathrm{~m}$ and average of maximum branch diameters in transects at Caulle sample sites. Sampling methods followed those used at Chaitén (Swanson et al. 2013). Observations made Jan. 6-9, 2012.

Número de ramas sobre el piso del bosque cada 100 m y diámetro promedio de ramas en transectos en los sitios de muestreo en el Caulle. Los métodos de muestreo siguen aquellos usados en el volcán Chaitén (Swanson et al. 2013). Observaciones realizadas en enero 6-9, 2012.

\begin{tabular}{lccc}
\hline Site & $\begin{array}{c}\text { Transect } \\
\text { length }(\mathrm{m})\end{array}$ & $\begin{array}{c}\text { Branches } \\
\text { per } 100 \mathrm{~m}\end{array}$ & $\begin{array}{c}\text { Average } \\
\text { diameter }(\mathrm{cm})\end{array}$ \\
\hline TdN10 & 80 & 5 & 3.6 \\
TdN25 & 100 & 20 & 2.7 \\
TdN35 & 100 & 8 & 3.3 \\
TdN50 & 100 & 17 & 2.7 \\
\hline
\end{tabular}

The forest at TdN35 was notable for the complete dominance of N. pumilio (all but a single tree of unknown species) in this young stand (mean dbh $16 \mathrm{~cm}$ ) and its high stem density $\left(2,233 \mathrm{ha}^{-1}\right)$, which was about three times the density of the other sites. Low variation in tree diameter (table 1) indicated that the forest established after a highseverity disturbance in the 1920 s, based on dendrochronology observations ${ }^{2}$, such as wildfire or the 1920-1921 Caulle eruption. Apparent survival from disturbance by $35 \mathrm{~cm}$ of tephra fall was high (only $2 \%$ of 268 trees sampled in the plot were killed by the eruption). After the main period of tephra deposition, sprouting appeared to be typical foliage production from terminal buds of branching networks rather 
than epicormic buds sprouting in response to disturbance. The number of branches on the tephra deposit surface intercepted along the transect was very small, and these may be from the numerous trees that were dead at the time of the eruption ( $23 \%$ of all upright tree stems in the plot) (table 2 ).

The TdN50 forest was composed of both Nothofagus species and, despite half a meter of tephra deposition, only about half the trees appeared to have been killed by the tephra fall. However, the immense majority of survivors were $N$. pumilio, and only a small fraction of $N$. dombeyi survived. Foliage sprouted from typical terminal buds at branch tips, and branch litter fall was low (table 2).

At both TdN35 and TdN50, we removed tephra at several locations and discovered evergreen $D$. andina shrubs with erect stems and green leaves in growth position within the tephra deposit (figure 4). The plants we had excavated in January 2012 still retained live foliage when we observed them again in December 2013. Moreover, the tops of shrubs emerged in many locations above the tephra deposits, but these twigs and leaves, even when connected to twigs with green foliage beneath the tephra, were dead (figure 3C).

The study transect along Route 215 presents an opportunity to study effects of a gradient of intensities of a single volcanic disturbance process - tephra fall - on native forest vegetation, but interpretation is complicated by variation in the structure and composition of the forest vegetation at the time of the eruption. Among the study sites the thickness of surface deposits and size of the largest pumice particles appeared to be uniform, but the thickness of the basal pumice gravel layer varied. In contrast with eruptions at Mount St. Helens and Chaitén, where ecological studies have addressed effects of diverse volcanic processes such as lateral blasts, mudflows, and pyroclastic flows as well as tephra fall (Dale et al. 2005, Swanson et al. 2013), we were able to observe only tephra fall effects in the Caulle study sites.

Along Route 215 transect tephra fall impacts on the forest ranged from negligible effects in areas that received a few centimeters of deposits to substantial mortality in areas where tephra thickness equaled or exceeded $25 \mathrm{~cm}$. Pre-eruption forest composition and structure varied substantially among sample sites, and this had a strong effect on tree mortality. For example, the young, vigorous deciduous $N$. pumilio trees were leafless at the initial stage of the eruption during the austral winter of 2011 (June - September), consequently they experienced very low mortality, even with $35 \mathrm{~cm}$ of tephra deposition. Conversely, the evergreen $N$. dombeyi trees exhibited substantial mortality even at the

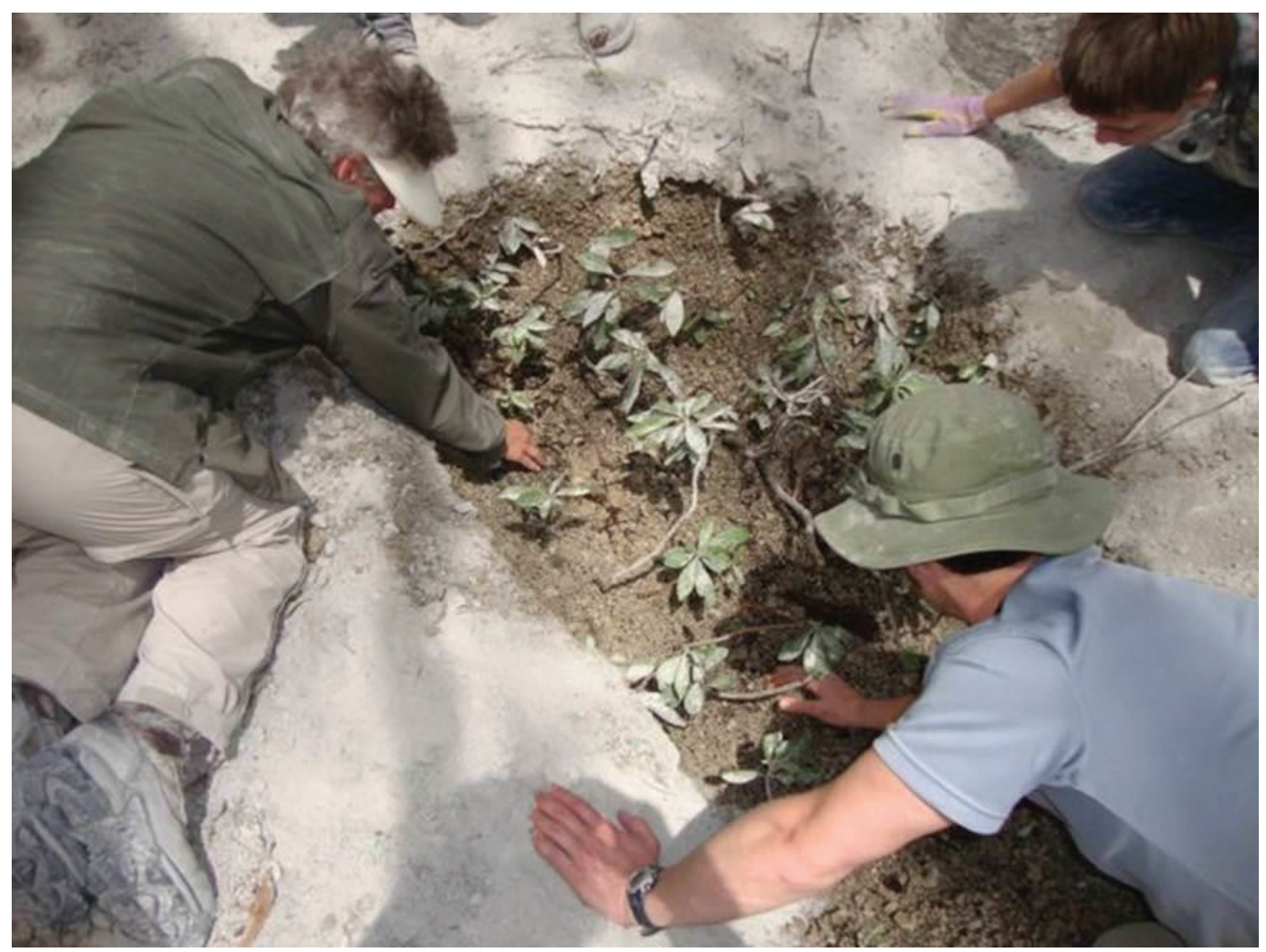

Figure 4. Removal of the new tephra deposits exposed the forest understory plant Drimys andina, which retains its growth form and green foliage, despite deposition of $35 \mathrm{~cm}$ of tephra with individual pumice clasts up to $6 \mathrm{~cm}$ (site TdN35). Photo: F Swanson, Jan. 2012.

Remoción de los depósitos recientes exponiendo la planta de sotobosque Drimys andina, la cual mantiene su forma de crecimiento y follaje verde, a pesar del depósito de $35 \mathrm{~cm}$ de tefra con clastos individuales de pumicita de hasta $6 \mathrm{~cm}$ (sitio TdN35). Fotografía: F Swanson, enero 2012. 
sites that received 10 and $25 \mathrm{~cm}$ of tephra. Clearly, tree species, age and season of eruption influence forest response along the gradient of tephra deposit thickness.

Many studies have examined effects of tephra deposition on forests, including physical and chemical effects of tephra on foliage and effects of tephra burial on survival and growth rates (Seymour et al. 1983, Antos and Zobel 1984, Hinckley et al. 1984, Segura et al. 1994, 1995, Ayris and Delmelle 2012). In our study tree survival/mortality was not simply related to total tephra fall depth, although the observed mortality patterns are consistent with the notion that thicker deposits are associated with higher forest mortality (Burt 1961, Ayris and Delmelle 2012, Swanson et al. 2013). At Mount St. Helens, growth decline depended on the depth of the fine tephra layer (Seymour et al. 1984). The depth of the fine tephra at Caulle did not vary consistently among plots and our study period was brief, thus we cannot examine that variable with our data.

Effects of deposition of the pumice-rich, gravel tephra on the forest near Caulle differ strikingly from canopy abrasion resulting from deposition of a lithic-rich gravel tephra NNE of Chaitén volcano (the beta tephra unit of Alfano et al. 2011, Swanson et al. 2013). During the 2008 eruption of Chaitén, deposition of 5 to $10 \mathrm{~cm}$ of tephra consisting of dense, lithic gravel fragments severely abraded the forest canopy, resulting in a high concentration of foliage and twigs in the lower part of the tephra deposit profile (Swanson et al. 2013). We looked for similar deposits of organic matter in the Caulle deposits beneath evergreen $N$. dombeyi trees, but we observed relatively low concentrations of foliage throughout the tephra profile, except in the upper few centimeters. In these upper layers, tephra entrained in the canopy may have fallen with abscised foliage, and throughfall drop splash may have mixed leaves and tephra once they were on the ground. We interpret the absence of a concentration of canopy organic matter in the lower tephra profile as an indicator of only minor canopy abrasion because the low bulk density of pumice gravel falling during the Caulle eruption apparently lacked the force necessary to detach foliage.

Forests affected by the Caulle eruption also lacked evidence of substantial limb litterfall. At Chaitén Swanson et al (2013) interpreted a high density of limbs on the ground surface in areas that received more than $10 \mathrm{~cm}$ of silt and sand tephra deposition to be the result of breakage in response to canopy loading. The 44 and 105 freshly broken limbs per $100 \mathrm{~m}$ transect (mean maximum diameter approximately $10 \mathrm{~cm}$ ) observed in transects at Chaitén significantly exceeds the 5 to 20 limbs per $100 \mathrm{~m}$ transect (mean diameter $=3.1 \mathrm{~cm}$ ) observed in the Caulle transects (table 2). Several factors may account for the lower limb fall at Caulle: 1) most of the tephra was gravel-sized pumice, leaves of the evergreen $N$. dombeyi are very small and smooth-surfaced, and twigs are more flexible compared to those of common species in the Chaitén area, such as Eucryphia cordifolia Cav., thus they did not retain coarse tephra, 2) much less fine sand was deposited at the Caulle sample sites compared to the sites where abundant limb fall occurred at Chaitén, and 3) the common species at Caulle, $N$. pumilio, is deciduous, hence leaves were not present to cause tephra retention in the canopy during the main tephra fall period. At Chaitén, most tephra fall-affected forest that Swanson et al. (2013) sampled was mature or old growth, but one plot dominated by young $N$. dombe$y i$, which received 10 to $15 \mathrm{~cm}$ of tephra fall, experienced very little mortality, indicating that young forests of both Nothofagus species may be more tolerant to deposition and burial by tephra (plot TF04, mean diameter $11 \mathrm{~cm}$, table 2 in Swanson et al. 2013).

The specific causes of tree mortality along our study transect remains unclear. Tephra fall has been associated with several mechanisms for tree decline or death, including acid deposition, ash deposition effects on foliar energy and water balances, and alteration of soil gas, energy, water exchange or chemical properties (Seymour et al. 1983, Hinckley et al. 1984, Segura et al. 1994, Ayris and Delmelle 2012). In this study, the larger mortality of evergreen $N$. dombeyi compared to deciduous $N$. pumilio, which was leafless at the time of the eruption, may provide indirect evidence that ash effects on foliage contributed to mortality. However, other mechanisms, such as acid deposition, are possible as well (e.g., Tognetti et al. 2012); although Nelson and Wheeler (2016) did not observe evidence of chemical damage in their study of lichens in our plots at Caulle.

Few studies have examined initial effects of other recent volcanic eruptions on forest structure in Chile. Veblen et al. (1996) observed snags of $N$. dombeyi whose mortality was attributed to the 1960 eruption of Puyehue, part of the same volcanic complex examined in this study. The violent eruption of Hudson volcano in the Aysén Region (45 50' S) in September 1991 deposited up to $1.8 \mathrm{~m}$ of tephra in some areas (Vogel et al. 1994, Besoain et al. 1995). Seventeen months after tephra fall Vogel et al. (1994) reported that Nothofagus spp. forests were able to tolerate more than $1 \mathrm{~m}$ of tephra deposition without visible damage, and only $N$. dombeyi trees presented broken branches. Similarly, limb breakage was observed on evergreen Nothofagus trees that may have been N. dombeyi or N. betuloides (Le Quesne 2002). The lack of reports of more severe damage from this eruption might be influenced by the fact that the remote location of Hudson precluded extensive observation of tree damage and mortality.

Erosion of new tephra deposits by water runoff has both facilitated and suppressed vegetation response after eruptions at other volcanoes. At Mount St. Helens, for example, rill and gully erosion down to the pre-eruption soil surface provided opportunity for sprouting of buried plant parts (Antos and Zobel 1984, Dale et al. 2005), but deeper and more extensive erosion removed plant propagules. However, we observed very few rills and gullies cut into the surface of the new Caulle deposits along Route 
215 at the time of our January 2012 visit, indicating that surface runoff from rainfall or snowmelt had been very limited, and any runoff was by sheet wash. During our 2013 visits we observed patterns of forest litter that indicated transport by surface runoff, but rills and gullies occupied a very small percent of the land surface in the vicinity of our plots and we observed negligible evidence of effects on vegetation response.

Some studies at other volcanoes report that the presence of snow at the time of eruption can affect vegetation response. At Mount St. Helens, for example, Antos and Zobel (1984) observed that the presence of late-spring snowpack suppressed recovery of understory vegetation buried under air-fall tephra. On the other hand, in the area affected by the lateral blast of Mount St. Helens, snow on the ground at the time of the eruption appeared to have protected plants within the snowpack from the heat of the lateral blast deposits, and subsequent melting of the snow disrupted tephra stratigraphy, facilitating plant growth to the surface.

Snow conditions during the eruption of Caulle are not well known, but records from a meteorological station at Cerro Mirador located in Argentina at 1,250 m a.s.l about $1.4 \mathrm{~km}$ from Cardenal Samoré Pass (1,309 m a.s.l) at the east end of our study transect indicate that snow was falling during the early phase of the Caulle eruption, with $100 \mathrm{~mm}$ of snow water equivalent accumulated in early June 2011 (AIC 2015, accessed 19 Oct. 2015). Snow water equivalent reached 1,500 $\mathrm{mm}$ in October, which substantially exceeded the mean of $1,150 \mathrm{~mm}$ for October at Cerro Mirador for the period 1996-2011. However, snow was incorporated in only the thin, upper layers of tephra deposits observed on June 15, 2011, at Cardenal Samoré Pass near our highest plots where tephra deposits exceeded $30 \mathrm{~cm}$ (figure 5). This suggests that during the main period of tephra fall snow and tephra fell simultaneously and heat of the tephra may have been sufficient to melt the snow either as it fell or while dispersed in the deposits. During our field studies, we observed no structures within or on the surface of the tephra deposits indicating disturbance by melting of buried snow. We urge that studies of future eruptions include detailed observations of the interactions among tephra deposits, snow and vegetation, including attention to the distinction between low-density, early-winter snow accumulations versus late-winter and high-density snow patches. Such studies need to pay close attention to geographic variation in snow conditions, which is substantial due to effects of elevation, aspect, forest cover and precipitation gradients imposed by orographic effects in mountain terrain.

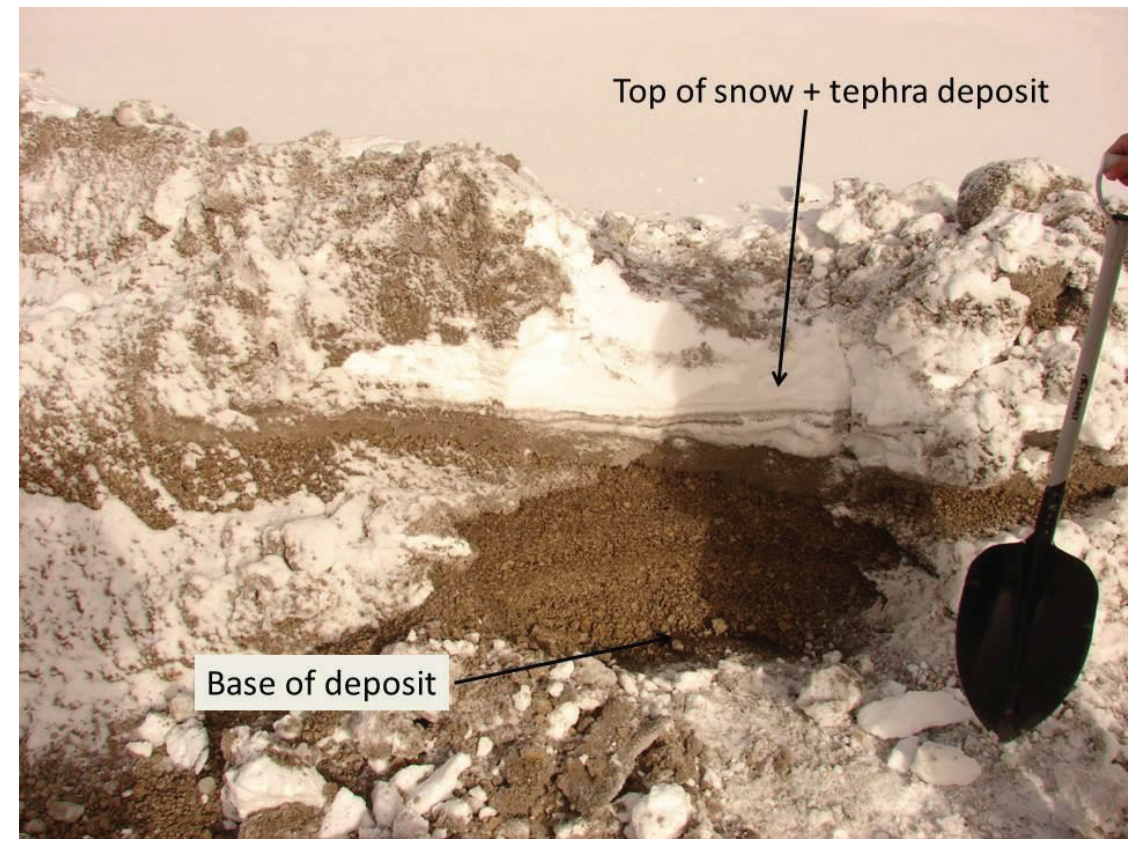

Figure 5. Tephra and snow profile at Cardenal Samoré Pass at the highest point on the transect shown in figure 2 . The deposit is composed of approximately $30 \mathrm{~cm}$ of tephra (approximate length of the shovel blade) with snow interbedded with several thin tephra deposits at the top of the profile. The faint stratigraphy evident in the main, fine-gravel tephra unit is similar to layering observed in pits dug at sample plots, indicating that the layering has not been disrupted by melting of snow below or incorporated within the tephra deposit. Photo: C Baumeister, Patagonia Expeditions, Anticura, Chile, June 15, 2011.

Tefra y perfil de nieve en Paso Cardenal Samoré en el punto más alto del transecto mostrado en figura 2. El depósito está compuesto por aproximadamente $30 \mathrm{~cm}$ de tefra (el largo de la hoja de la pala) con nieve intercalada con varios depósitos finos de tefra en la parte superior del perfil. La fina estratigrafía evidente en la principal unidad de tefra de clasto fino es similar a la estratigrafía observada en los hoyos excavados en las parcelas muestreadas, indicando que las capas no han sido alteradas por el derretimiento de la nieve de abajo o incorporado dentro del depósito de tefra. Foto: C Baumeister, Patagonia Expeditions, Anticura, Chile, 15 de junio, 2011. 
The lack of conspicuous physical damage to overstory and understory vegetation; the lack of breakage of even fine twigs in tree canopies; the presence of shrubs, even those with spindly stems, in erect form within and emerging from the tephra; and the presence of leaves in growth position within the tephra deposits that were able to survive once excavated, all point to a gradual, gentle deposition of tephra at Caulle. This contrasts sharply with descriptions of severe tephra effects observed at Chaitén and other volcanoes (Ayris and Delmelle 2012, Swanson et al. 2013).

Our studies at Caulle, Chaitén, and Mount St. Helens make the importance of four components in studying ecological responses to eruptions clear. First, an interdisciplinary approach is essential to elucidating interactions between volcanic and ecologic processes. Second, studies initiated very soon after, and even during eruptions may reveal evidence of volcanic and ecological mechanisms and responses, including the roles of snow, that quickly disappear. Third, repeated observations over many years (e.g., Segura et al. 1995, Biondi et al. 2003) are essential to document lagged responses to disturbance, such as delayed mortality or slow expression of survival, as well as the slow pace of forest succession and influences of secondary disturbances. Finally, previous surveys of species distributions and ecosystem conditions are a critical foundation for evaluating ecological responses to any disturbance, so we strongly support basic ecological inventories.

\section{ACKNOWLEDGEMENTS}

We highly appreciate the assistance of students of Universidad Austral de Chile, lichenologists Peter Nelson and Tim Wheeler, Rocío Marticorena for discussion of snow records, and especially Cristian Baumeister and other staff of Patagonia Expeditions, Anticura, Chile. This work was supported by US National Science Foundation grants 0823380 and 0917697, the US Forest Service Pacific Northwest Research Station, Dirección de Investigación y Desarrollo (DID), Universidad Austral de Chile, and Center for Climate and Resilience Research (CR) ${ }^{2}$ (CONICYT/ FONDAP/15110009).

\section{REFERENCES}

Alfano F, C Bonadonna, ACM Volentik, CB Connor, SFL Watt, DM Pyle, LJ Connor. 2011. Tephra stratigraphy and eruptive volume of the May, 2008, Chaitén eruption, Chile. Bulletin of Volcanology 73:613-630.

Antos JA, DB Zobel. 1984. Snowpack modification of volcanic tephra effects on forest understory plants near Mount St. Helens. Ecology 63:1969-1972.

AIC (Autoridad Interjurisdiccional de las Cuencas de los Ríos Limay, Neuquén y Negro, AR). 2014. Accessed Oct.19, 2015. Available at www.aic.gov.ar/aic/publicaciones.aspx

Ayris PM, P Delmelle. 2012. The immediate environmental effects of tephra emission. Bulletin of Volcanology 74:1905-1936

Besoain E, RS Ruiz, C Hepp. 1995. La erupción del Volcán Hud- son, XI Región, y sus consecuencias para la agricultura. Agricultura Técnica 55:204-219.

Biondi F, IG Estrada, JC Gavilanes Ruiz, AE Torres. 2003. Tree growth response to the 1913 eruption of Volcán de Fuegode Colima, Mexico. Quaternary Research 59:293-299.

Burt WH. 1961. Some effects of Volcán Parícutin on vertebrates. Occasional Papers of the Museum of Zoology (University of Michigan) 620:1-24.

Castro JM, CI Schipper, SP Mueller, AS Militzer, A Amigo, CS Parejas, D Jacob. 2013. Storage and eruption of near-liquidus rhyolite magma at Cordón-Caulle, Chile. Bulletin of Volcanology 75:702-719.

Crisafulli CM, FJ Swanson, JJ Halvorson, B Clarkson. 2015. Volcano ecology: disturbance characteristics and assembly of biological communities, In Sigurdsson H, B Houghton, S McNutt, H Rymer, J Stix editors. Encyclopedia of volcanoes. 2nd edition. London, UK. Elsevier Publishing. p. 1265-1284.

Dale VA, FJ Swanson, CM Crisafulli (editors). 2005. Ecological responses to the 1980 eruption of Mount St. Helens. New York, NY, USA. Springer. 342 p.

Donoso C, ME González, A Lara, (editors). 2014. Ecología forestal: bases para el manejo sustentable y conservación de los bosques nativos de Chile. Valdivia, Chile. Ediciones Universidad Austral de Chile. 720 p.

Hinckley TM, H Imoto, K Lee, S Lacker, Y Morikawa, KA Vogt, CC Grier, MR Keyes, RO Teskey, V Seymour 1984. Impact of tephra deposition on growth of conifers: the year of the eruption. Canadian Journal of Forest Research 14:731-739.

Le Quesne C. 2002. Bioecología del bosque nativo chileno. In Baldini A, L Pancel eds. Agentes de daño en el bosque nativo. Santiago, Chile. Editorial Universitaria. p. 19-44.

Nelson PR, TB Wheeler. 2016. Persistence of epiphytic lichens along a tephra-depth gradient produced by the 2011 Cordón-Caulle eruption in Parque Nacional Puyehue, Chile. Bosque 37(1): 97-105.

Pallister JS, JJ Major, TC Pierson, RP Hoblitt, JB Lowenstern, JC Eichelberger, L Lara, H Moreno, J Munoz, JM Castro, A Iroume, A Andreoli, J Jones, F Swanson, C Crisafulli. 2010. Interdisciplinary studies of eruption at Chaitén Volcano, Chile. EOS, Transactions of American Geophysical Union 91(42):381-392.

Seymour VA, TM Hinckley, Y Morikawa, JF Franklin. 1983. Foliage damage in coniferous trees following volcanic ashfall from Mt. St. Helens. Oecologia 59:339-343.

Segura G, LB Brubaker, JF Franklin, TM Hinckley, DA Maguire, G Wright. 1994. Recent mortality and decline in mature Abies amabilis: the interaction between site factors and tephra deposition from Mount St. Helens. Canadian Journal of Forest Research 24:1112-1122.

Segura G, TM Hinckley, LB Brubaker. 1995. Variations in radial growth of declining old-growth stands of Abies amabilis after tephra deposition at Mount St. Helens. Canadian Journal of Forest Research 25:1484-1492.

Singer BS, BR Jicha, MA Harper, JA Naranjo, LE Lara, H Moreno-Roa. 2008. Eruptive history, geochronology, and magmatic evolution of the Puyehue-Cordón Caulle volcanic complex, Chile. Geological Society of America Bulletin 120:599-618.

Swanson FJ, JA Jones, CM Crisafulli, A Lara. 2013. Effects of volcanic and hydrologic processes on forest vegetation: Chaitén Volcano, Chile. Andean Geology 40(2):359-391. 
DOI: 10.5027/andgeoV40n2-a10.

Tognetti R, F Lombardi, B Lasserre, G Battipaglia, M Saurer, P Cherubin, M Marchetti. 2012. Tree-ring responses in Araucaria araucana to two major eruptions of Lonquimay Volcano (Chile). Trees 26(6): 1805-1819. DOI: 10.1007/ s00468-012-0749-9.

Veblen TT, DH Ashton, FM Schlegel, AT Veblen. 1977. Plant succession in a timberline depressed by vulcanism in southcentral Chile. Journal of Biogeography 4:275-294.
Veblen TT, C Donoso, T Kitzberger, AJ Rebertus. 1996. Ecology of southern Chilean and Argentinian Nothofagus forests. In Veblen TT, RS Hill, J Read eds. The ecology and biogeography of Nothofagus forests. London, UK. Yale University Press. p. 293-353.

Vogel A, R Hildebrand-Vogel, R Godoy. 1994. Auswirkungen eines Aschefalls auf die Vegetation eines Südbuchenwaldes in Westpatagonien. Verhandlungen der Gesellschaft für Ökologie 23:177-186.

Recibido: 24.01 .15

Aceptado: 16.11 .15 